\title{
Experimental operation and performance evaluation of waste remover in aquaculture ponds
}

\author{
Le The Truyen ${ }^{1, *}$, Le Thanh Long ${ }^{2}$
}

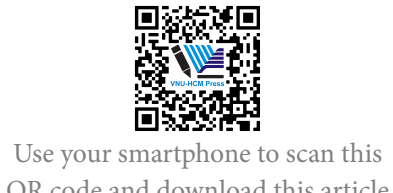

QR code and download this article

${ }^{1}$ Key Laboratory of Digital Control and System Engineering, HCMUT

(DCSELAB), VNU-HCM, Vietnam.

${ }^{2}$ Faculty of Mechanical Engineering, Ho Chi Minh University of Technology, VNU-HCM, Vietnam.

Correspondence

Le The Truyen, Key Laboratory of Digital Control and System Engineering, HCMUT (DCSELAB), VNU-HCM, Vietnam.

Email: truyenlt@hcmut.edu.vn

History

- Received: $12 / 10 / 2018$

- Accepted: 24/12/2018

- Published: 31/12/2019

DOI : 10.32508/stdjet.v3iSI1.730

\section{Check for updates}

\section{Copyright}

(c) VNU-HCM Press. This is an openaccess article distributed under the terms of the Creative Commons Attribution 4.0 International license.

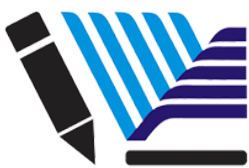

VNU-HCM Press

\section{ABSTRACT}

The development of new technologies in automation to increase labor productivity has been increasingly enhanced in recent decades. The problem of cleaning water in shrimp ponds greatly affects the quality as well as shrimp production. Environmental pollution of shrimp farming is a matter of concern because the current waste treatment solutions are not yet thorough. A waste remover of shrimp waste combined with pond bottom siphon method has been researched and developed to increase the ability to thoroughly handle waste generated in the culture environment. This device helps to automate the manual cleaning of the pond bottom by farmers. The device performs operations to clean waste, suck, filter and remove waste from the culture environment. This device is self-propelled or manually controlled and operates in all weather conditions. This article introduces the process of testing and evaluating the efficiency of waste extraction equipment in shrimp ponds. The device was tested at a super intensive shrimp farm and evaluated for operational efficiency. The experimental model consists of a shrimp pond operating a waste suction device, a control pond, an automatic monitoring system of water quality parameters $\left(\mathrm{DO}, \mathrm{H}_{2} \mathrm{~S}, \mathrm{NH}_{3}\right.$, $\mathrm{pH}$ and temperature). Experimental ponds operating waste disposal equipment, control ponds are manually cleaned, other farming conditions of the two ponds are similar. The impacts of waste on shrimp culture environment are determined through analyzing the results of measuring water quality criteria in the pond, thereby assessing the efficiency of waste removal of the equipment. The measurement results show that water quality parameters reach a value within the threshold if operating a waste suction device once per day. The benefits of waste remover operate are to help save the cost of labor to clean the pond bottom, protect workers' health.

Key words: Aquaculture ponds, Siphon, Waste remover., Water quality

\section{INTRODUCTION}

Brackish water shrimp farming is an important economic industry of Vietnam with current export in amount of USD 3.85 billion and expected export in 2025 is USD 10 billion.

To increase productivity, high tech intensive and supper intensive shrimp farming methods are implemented to production practice with increasing proportion.

The area of high-tech shrimp farming is planned to be 100,000 ha in 2020.

The main features of high-tech shrimp farming are using small ponds (less than $1000 \mathrm{~m}^{2}$ ) with bottom lined by HDPE sheets to isolate the rearing environment from negative factors such as: Acid sulfate soil, harmful microorganisms from earthen pond bottoms.

Although HDPE line bottom eases solid waste collecting in the center of the pond by paddle wheels ${ }^{1}$ (then waste will be removed from pond), part of solid waste is still settled on the bottom and stick to the HDPE surface. This layer of the organic material also be- comes the favorable environment for harmful bacteria to grow. It is observed that there is a sticky, slippery layer on the surface and it is not easy to be removed just by water flow caused by paddle wheels. Most of the waste is collected in the siphon pit, but the rest need to be removed from the pond. Significant sludge buildup may negatively affect the target crop by increasing biological oxygen demand, reducing usable habitat, decreasing availability of natural prey organisms and releasing toxic compounds ${ }^{2}$. Typically, effluents from aquaculture are characterized by increased nitrogen species (ammonia, nitrites, and nitrates), organic carbon, phosphates, suspended solids, and high biological oxygen demand (BOD) and chemical oxygen demand (COD) ${ }^{3}$. Significant issues can result in the release of nutrient rich effluents such as these including increased algal blooms, degradation of benthic communities, oxygen depletion, and overall degraded water quality ${ }^{4}$. Successful shrimp aquaculture requires maintenance of water quality conducive for the growth of shrimp. Common water quality concerns for shrimp aquaculture 
include inorganic suspended solids (ISS), total suspended solids (TSS), biochemical oxygen demand (BOD), chemical oxygen demand (COD), dissolved oxygen (DO), and nitrogen ${ }^{5,6}$. To remove this layer from the HDPE surface, mechanical force should be applied.

Currently, every day, workers in farm should get down to the pond, with long handle cleaning brush to rub the surface to remove waste stick to HDPE surface of pond bottom. The waste removed from HDPE line will be mixed with the pond water, and then collected to the center of pond thank circle flow created by paddle wheels.

This is not only hard and harmful work for worker health, but also it becomes difficult to find workers who agree to do this work. Development of an automated waste remover from HDPE pond bottom becomes indispensable. Some characteristics of HDPE pond bottom are favorable to use machines to remove waste on the surface are: a) having enough flatness for mechanical equipment moving; b) having high stiffness and not easy to be dug under impact of mechanical force of cleaning and waste removing processes. Based on above mentioned, an automated waste remover is designed, developed and tested to evaluate its performance and effectiveness for further development and application.

\section{MATERIALS AND METHODS}

\section{Working principle and equipment structure}

The completely manufacturing waste remover was tested at a shrimp farm in Can Gio District, Ho Chi Minh City (Figure 1).

The device moves on the bottom of the pond, with two operating modes: self-propelled and manually controlled via a remote control. During operation, the axial pump has a suction tube diameter of up to 120 $\mathrm{mm}$ and a suction flow of $40 \mathrm{~m}^{3} / \mathrm{h}$ is arranged to draw waste on the bottom pond according to water stream into the filter bag. Axial pump has a three blades impeller, powered by a $170 \mathrm{~W}$ motor. The device travels at a maximum speed of $15 \mathrm{~m} / \mathrm{s}$ through the friction between the tooth belt outer surface and the lining of the pond bottom. Two power $47 \mathrm{~W}$ servo DC motors are used to transmit motion to the two drive axles and are independently controlled. The brush shaft is arranged horizontally in front of and behind the device received drive from the two passive shafts via the transmission gear has ratio 2.15. The two brushing shafts are coated with soft bristles to brush the waste on the bottom of the pond, swirled them into under device and be sucked into the filter bag. The operating

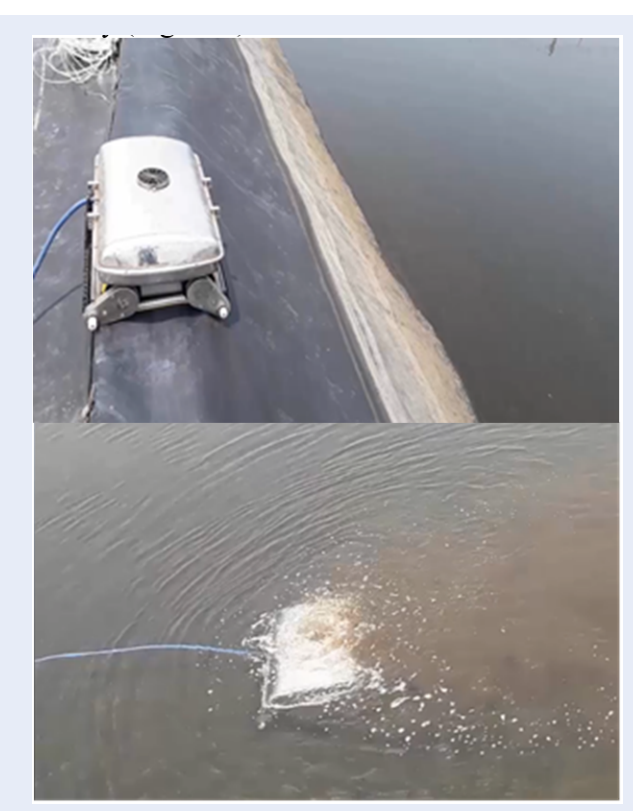

Figure 1: The waste remover during operation.

parameters of device: speed: $15 \mathrm{~m} / \mathrm{min}$; total power: $500 \mathrm{~W}$; flow: $40 \mathrm{~m}^{3} / \mathrm{h}$.

The schematic diagram (Figure 2) illustrates the arrangement of main components and the motions when the equipment is operating.

The control system of the waste remover (Figure 3) uses two microcontrollers on the central control board and the control board communicates with each other and receives control information from the user and executes control commands for three motors.

\section{Trial run and evaluation}

Experiment is carried out in 2 shrimp pond in Can Gio District of Ho Chi Minh City; from these 2 ponds, 1 st is experimental pond, and 2nd pond is controlled pond.

The experiment is implemented during 15 days, from April 10, 2018 to April 25, 2018.

Experimental conditions are listed in Table 1.

\section{RESULTS AND DISCUSSION}

\section{Water quality}

During testing period, water quality parameters, such as dissolved oxygen (DO), temperature, $\mathrm{pH}$, and concentration of $\mathrm{H}_{2} \mathrm{~S}, \mathrm{NH}_{3}$ are measured ${ }^{7}$.

The condition of measurement such as: equipment, sensors, and frequency are listed in Table 2.

There is no temperature adjustment equipment then water temperature depends on the environment tem- 

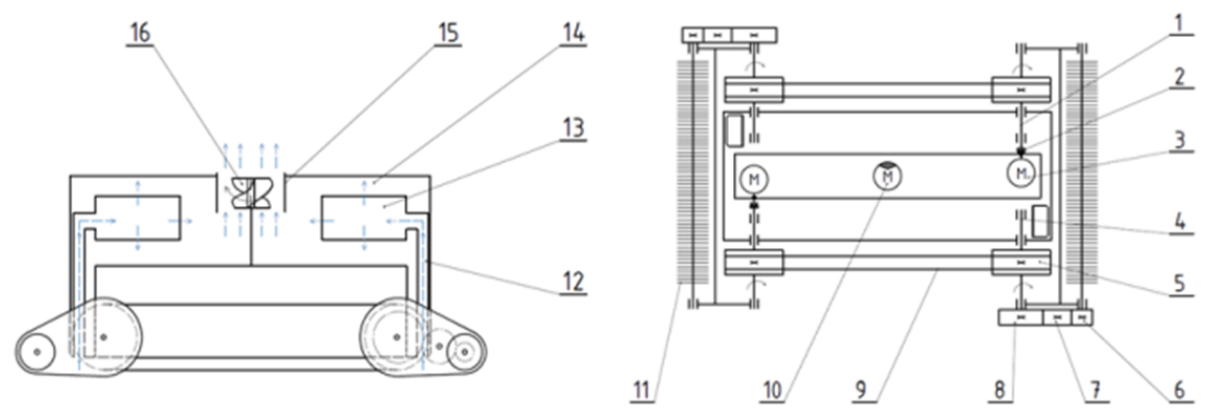

Figure 2: The schematic diagram of the waste remover ${ }^{a}$

${ }^{a}$ 1-Active shaft; 2-Shaft coupling; 3-Motor; 4-Passive shaft; 5-Transmission belt; 6-Passive gear; 7-Intermediate gear; 8-Active gear; 9-Belt; 10-Pump; 11-Brushing shaft; 12-Suction pipe; 13-Filter bags; 14-Body cavity; 15-Outlet pipe; 16-Impeller.
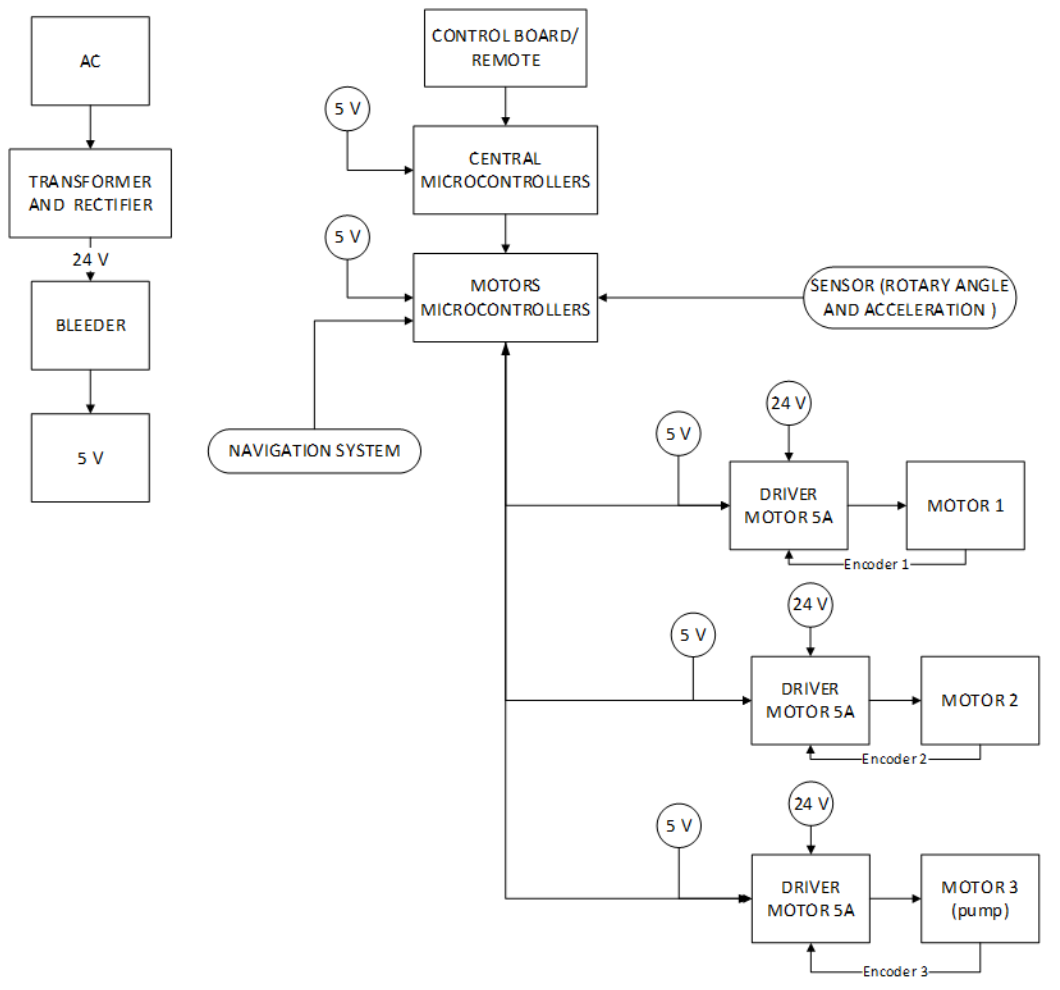

Figure 3: The control system of the waste remover. 


\begin{tabular}{lcc}
\hline Table 1: Experimental conditions & & \\
\hline Parameter & Experimental pond & Controlled pond \\
Size of the pond & $1000 \mathrm{~m}^{2}$ & $1000 \mathrm{~m}^{2}$ \\
Bottom & HDPE lined & \\
Rearing animals & White leg shrimp \\
Density & 200 post / $\mathrm{m}^{2}$ \\
Crop starting day & February 23, 2018 \\
Cleaning method from Feb 23 to April 10, 2018 & Manual \\
Cleaning from April 10 (age of shrimp 46 days) to April 25, 2018 & By waste remover \\
Average time for daily pond cleaning & 90 minutes & Manual \\
Cleaning after April 25, 2018 & Manual & 180 minutes \\
\hline
\end{tabular}

perature. Water temperature during experiment varied from $28^{\circ} \mathrm{C}$ to $32^{\circ} \mathrm{C}$, and is the same in both ponds. Dissolved oxygen is adjusted by aeration equipment and it is kept the same in both ponds, in level from $4.0 \mathrm{ppm}$ to $6.8 \mathrm{ppm}$.

$\mathrm{pH}$ is adjusted by adding calcium oxide $(\mathrm{CaO})$ and molasses to keep this value the same in both ponds and in level from 7.5 - 8.0. Adding calcium oxide $(\mathrm{CaO})$ and molasses is carried out twice a day, at 6:00 am and 17:00 pm.

Probiotics are added to the both ponds in the same scheme.

Siphon and water change is the same for both ponds during testing period.

The results of $\mathrm{H}_{2} \mathrm{~S}$ measurement during 15 days show that water does not contain $\mathrm{H}_{2} \mathrm{~S}$. This is explained by fact that there is very little sludge accumulation at the bottom because bottom is cleaned daily manually or by waste remover.

The $\mathrm{NH}_{3}$ measuring results (ppm) during 15 days are presented in Figure 4.

Statistical data of $\mathrm{NH}^{4+}$ measurement results is listed in Table 3.

The test results show that water quality in both ponds are the same and waste remover can ensure quality of bottom as the same as manual cleaning, or another ways speaking, manual cleaning totally can be replace by cleaning using waste remover.

\section{Social and economic effectiveness}

The most valuable benefit of waste remover is to protect the health of workers and ensure the daily cleaning of pond bottom even in case cleaner is not available for keeping pond bottom in good condition. Monthly expenses for 1 worker are about USD 400, and 1 worker can clean 2 ponds a day.
Waste remover can clean 6 ponds with one worker. Then, the monthly saving is expenses for 2 workers in amount of 800 USD. That means yearly manpower saving is USD 9,600.

Additional expenses are electricity and maintenance cost is about USD 1,600/ year.

The planned sale price is USD 8000 and then equipment is paid back after one year.

Using waste remover twice daily to improve water quality requires additional study.

\section{CONCLUSION}

- Waste remover can work well on HDPE shrimp pond bottom.

- 1 time per day cleaning by waste remover gives the same water quality in comparison with manual cleaning.

- Waste remover can save worker's health and help to solve the manpower shortage.

- Waste remover expected to be paid back after 1 year. - Additional study is required for 2 times cleaning using waste remover to improve water quality and electricity saving.

\section{ABBREVIATIONS}

HDPE: High-density polyethylene

BOD: Biochemical Oxygen Demand

COD: Chemical Oxygen Demand

TSS: Total Suspended Solids

DO: Dissolved Oxygen

ISS: Inorganic Suspended Solids

DC: Direct Current

\section{CONFLICT OF INTEREST}

The authors wish to confirm that there are no know conflicts of interest associated with this publication 
Table 2: Conditions of water quality measurement

\begin{tabular}{|c|c|c|c|}
\hline Parameter & Measuring method & Sensor/ Equipment & Frequency \\
\hline Dissolved oxygen & Automatic & Sensorex DO6442TC/T & 1 time/ $1 \mathrm{hr}$. \\
\hline Temperature & Automatic & $\begin{array}{l}\text { Vernier EasyTemp EZ- } \\
\text { TMP }\end{array}$ & 1 time/ $1 \mathrm{hr}$. \\
\hline $\mathrm{pH}$ & Automatic & HANNA HI6100805 & 1 time/ 1 hr. \\
\hline $\mathrm{H}_{2} \mathrm{~S}$ & Manual & $\begin{array}{l}\text { HI } 83200 \text { Multiparame- } \\
\text { ter Bench }\end{array}$ & 1 time/ day at $15: 00 \mathrm{pm}$ \\
\hline $\mathrm{NH}_{3}$ & Manual & $\begin{array}{l}\text { Photometer for Labora- } \\
\text { tories }\end{array}$ & \\
\hline
\end{tabular}

\section{$\mathrm{NH}_{3}$ measurement results}

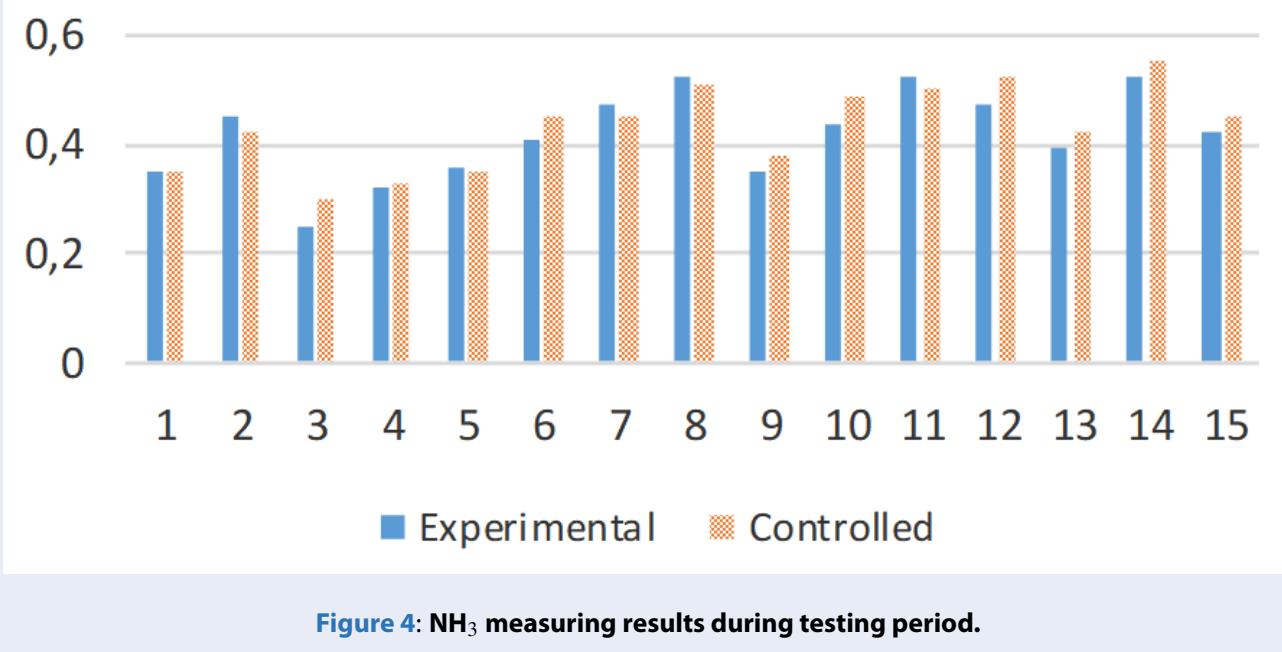

Table 3: Statistical data of $\mathbf{N H}^{+}$measurement

\begin{tabular}{lcc}
\hline Parameters & Experimental pond & Controlled pond \\
Average $\mathrm{NH}_{3}$ concentration, ppm & 0.41 & 0.46 \\
Standard deviation, $\%$ & 7.7 & 7.3 \\
\hline
\end{tabular}

and there has been no significant financial support for this work that could have influenced its outcome.

\section{AUTHOR CONTRIBUTION}

All authors conceived of the study and participated in its design and coordination and helped to draft the manuscript. The authors read and approved the final manuscript.

\section{ACKNOWLEDGEMENT}

This research is supported by DCSELAB and funded by Vietnam National University Ho Chi Minh City (VNU-HCM) under grant number B2017-20b-01.

\section{REFERENCES}

1. Avnimelech $Y$, Ritvo G. Shrimp and fish pond soils: processes and management. Aquaculture. 2003;220(1):549-567. Available from: https://doi.org/10.1016/S0044-8486(02)00641-5.

2. Delgado PC, Avnimelech Y, McNeil R, Bratvold D, Browdy CL, PS. Physical, chemical and biological characteristics of distinctive regions in paddlewheel aerated shrimp ponds. Aquaculture. 2003;217(1):235-248. Available from: https://doi.org/10.1016/ S0044-8486(02)00231-4.

3. Boopathy $R$, Lyles $C$. Shrimp production and biological treatment of shrimp wastewater in the United States. Aquaculture. 2008;226:101-112.

4. Boyd C. Guidelines for aquaculture effluent management at the farm-level. Aquaculture. 2003;226:101-112. Available from: 
https://doi.org/10.1016/S0044-8486(03)00471-X.

5. Boopathy R, Fontenot Q, Kilgen M. Biological Treatment of Sludge from a Recirculating Aquaculture System Using a Sequencing Batch Reactor. Journal of The World Aquaculture Society - J WORLD AQUACULT SOC . 2005;36:542-545. Available from: https://doi.org/10.1111/j.1749-7345.2005.tb00403.x.

6. Boopathy R, Bonvillain C, Fontenot Q, Kilgen M. Biological treatment of low-salinity shrimp aquaculture wastewater us- ing sequencing batch reactor. International Biodeterioration \& Biodegradation. 2007;59(1):16-19. Available from: https://doi. org/10.1016/j.ibiod.2006.05.003.

7. Hossain MA, Sarker AK, Amin MN, Hossain MM, Miah MS. Development and performance evaluation of sludge remover for intensive aquaculture. Aquacultural Engineering. 2016;74:6269. Available from: https://doi.org/10.1016/j.aquaeng.2016.06. 001. 


\title{
Vận hành thử nghiệm và đánh giá hiệu quả vận hành thiết bị hút chất thải trong các ao nuôi thủy sản
}

\author{
Lê Thể Truyền ${ }^{1, *}$, Lê Thành Long ${ }^{2}$
}

${ }^{1} P T N$ Trong diêm Điều khiển số và Kỹ thuật Hệ thống, Trường ĐH Bách khoa, ĐHQG-HCM; Việt Nam

${ }^{2}$ Khoa Cơ khí, Trường Đại học Bách khoa, ĐHQG-HCM, Việt Nam

Liên hệ

Lê Thể Truyền, PTN Trọng điểm Điều khiển số và Kỹ thuật Hệ thống, Trường ĐH Bách khoa, ĐHQG-HCM; Việt Nam

Email: truyenlt@hcmut.edu.vn

Lịch sử

- Ngày nhận: 12/10/2018

- Ngày chấp nhận: 24/12/2018

- Ngày đăng: 31/12/2019

DOI : 0.32508/stdjet.v3iSI1.730

\section{Check for updates}

\section{Bản quyền}

๑ ĐHQG Tp.HCM. Đây là bài báo công bố mở được phát hành theo các điều khoản của the Creative Commons Attribution 4.0

International license.

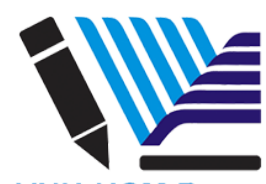

VNU-HCM Press

\section{TÓM TẮT}

Sự phát triển của các công nghệ mới trong tự động hóa nhằm tăng hiệu suất lao động ngày càng được tăng cường trong những thập kỷ gần đây. Vấn đề làm sạch nước trong ao nuôi tôm ảnh hưởng rất lớn đến chất lượng cũng như sản lượng tôm. Ô nhiễm môi trường nuôi tôm đang là vấn đề được quan tâm vì các giải pháp xử lý chất thải hiện nay vẫn chưa triệt để. Một thiết bị hút chất thải nuôi tôm kết hợp với phương pháp siphon đáy ao đã được nghiên cứu và phát triển để tăng khả năng xử lý triệt để chất thải phát sinh trong môi trường nuôi. Thiết bị này giúp tự động hóa quá trình vệ sinh đáy ao thủ công của người nông dân. Thiết bị thực hiện các hoạt động chải sạch chất thải, hút, lọc và loại bỏ chất thải ra khỏi môi trường nuôi. Thiết bị này có thể tự hành hoặc được điều khiển bằng tay và hoạt động trong mọi điều kiện thời tiết. Bài báo này giới thiệu quá trình vận hành thử nghiệm và đánh giá hiệu quả thiết bị hút chất thải trong ao nuôi tôm. Thiết bị được thử nghiệm tại một trang trại nuôi tôm siêu thâm canh và đánh giá hiệu quả vận hành. Mô hình thử nghiệm gồm một ao nuôi tôm vận hành thiết bị hút chất thải, một ao đối chứng, một hệ thống giám sát tự động các thông số chất lượng nước $\left(\mathrm{DO}, \mathrm{H}_{2} \mathrm{~S}, \mathrm{NH}_{3}\right.$, pH và nhiệt độ). Ao thư nghiệm vận hành thiết bị hút chất thải, ao đối chứng được vệ sinh thủ công, các điều kiện nuôi trồng khác của 2 ao là tương tự nhau. Các tác động của chất thải tới môi trường nuôi tôm được xác định thông qua phân tích kết quả đo các chỉ tiêu chất lượng nước trong ao nuôi, từ đó có thể đánh giá hiệu quả loại bỏ chất thải của thiết bị. Các kết quả đo cho thấy các thông số chất lượng nước đạt giá trị trong ngưỡng cho phép nếu vận hành thiết bị hút chất thải một lần mỗi ngày. Lợi ích mang lại của việc vận hành thiết bị hút chất thải là giúp tiết kiệm chị phí nhần công vệ sinh đáy ao, bảo vệ sức khỏe người lao động.

Từ khoá: Ao nuôi thủy sản, Chất lượng nước, Siphon, Thiết bị hút chất thải
Trích dẫn bài báo này: Truyền $L T$, Long $L T$. Vận hành thử nghiệm và đánh giá hiệu quả vận hành thiết bị hút chất thải trong các ao nuôi thủy sản. Sci. Tech. Dev. J. - Eng. Tech.; 2(SI1):SI120-SI126. 